\title{
PERAN KINERJA KEUANGAN DALAM MENENTUAN NILAI PERUSAHAAN
}

\section{Sri Murni, Harijanto Sabijono}

Universitas Sam Ratulangi

A R T I C L E I N F O

\author{
Keywords : $C A R, L D R, N P L$, \\ DER,ROE, Corporate Value
}

Kata Kunci : $\quad C A R, L D R, N P L$, DER, ROE, Nilai Perusahaan

Corresponding author :

Sri Murni

srimurnirustandi@unsrat.ac.id
Abstract: this research aims to know the influence of CAR, LDR, NPL, DER and $R O E$ of the company simultaneously or partial on the banking sector, which is listed on the Indonesia stock exchange. Methods of analysis used in this study is the associative method with multiple regression analysis techniques and pengujuan classical assumptions. The data used are secondary data sourced from Indonesian Capital Market Directory (ICMD) as well as the Annual Report of the Indonesia Stock Exchange (IDX) in the form of the financial statements of the period 2006-2015 years in the banking sector, which is listed on the stock exchange Indonesia. This research is expected to be especially valuable insert for investors as a consideration in decisions to invest in the capital market, also for the management of the company are expected to be consideration in taking a decision against the stock price in order to maximize the value of the company. The results showed that the simultaneous CAR, LDR, NPL, DER and the ROE effect significantly to the value of the company. Partially DER very influential negative and significantly to the value of the company, CAR and NPL positive and significant effect against the value of the company, while the LDR and ROE had no significant influence on the value of the company.

Abstrak : Penelitian ini bertujuan untuk mengetahui pengaruh CAR, LDR, NPL, DER dan ROE terhadap Nilai Perusahaan secara simultan ataupun parsial pada Sektor Perbankan yang terdaftar di Bursa Efek Indonesia. Metode analisa yang digunakan dalam penelitian ini adalah metode asosiatif dengan teknik analisis regresi berganda dan pengujuan asumsi klasik. Data yang digunakan adalah data sekunder yang bersumber dari Indonesian Capital Market Directory (ICMD) serta Annual Report dari Indonesia Stock Exchange (IDX) berupa laporan keuangan periode tahun 2006-2015 pada Sektor Perbankan yang terdaftar di Bursa Efek Indonesia.Penelitian ini diharapkan dapat menjadi masukkan berharga terutama bagi para investor sebagai bahan pertimbangan dalam pengambilan keputusan berinvestasi di pasar modal, juga bagi manajemen perusahaan diharapkan dapat menjadi bahan pertimbangan dalam mengambil keputusan terhadap harga saham agar dapat memaksimalkan nilai perusahaan.Hasil penelitian menunjukkan bahwa secara simultan CAR, LDR, NPL, DER dan ROE berpengaruh signifikan terhadap Nilai Perusahaan. Secara parsial DER sangat berpengaruh negative dan signifikan terhadap Nilai perusahaan, CAR dan NPL berpengaruh positif dan signifikan terhadap Nilai Perusahaan, sedangkan LDR dan ROE mempunyai pengaruh yang tidak signifikan terhadap Nilai Perusahaan. 


\section{Latar Belakang}

\section{PENDAHULUAN}

Investor pasar modal tidak perlu khawatir dengan pemberlakukan Masyarakat Ekonomi Eropa (MEA). Investor malah yakin mereka akan diuntungan jika integrasi pasar modal yang menjadi salah satu priorotas MEA bisa terlaksana. Perbakan nasional juga harus berperan aktif mengantisipasi pemberlakuan MEA. Era bebas pasar ini, dipastikan akan membuka alur lalu lintas barang dan jasa semakin lebar, karenanya pertumbuhan ekonomi regional harus terintegrasi dengan ekonomi global. Dengan demikian, perbankan nasional memerlukan kesamaan pandang dalam melihat pertumbuhan ekonomi regional. Dengan kesamaan pandang itu, diharapkan perbakan Indonesia dapat menyelesaikan rencana, strategi, sasaran yang tepat bagi kemajuan ekonomi Indonesia.

Di era globalisasi saat ini banyak lembaga keuangan yang tumbuh dan berkembang secara cepat dalam perekonomian Indonesia, antara lain lembaga keuangan bank yang merupakan badan usaha yang berfungsi menghimpun dana dari masyarakat dalam bentuk simpanan dan menyalurkannya kepada masyarakat dalam bentuk kredit dan atau bentuk-bentuk lainnya dalam rangka meningkatkan taraf hidup rakyat banyak. Peran perbankan bagi perkembangan perekonomian Indonesia, sangat penting, banyak investor yang tertarik untuk melakukan investasi di sektor perbankan dan dalam melakukan investasi, tentunya investor perlu melihat tingkat kesahatan bank. Saat ini ada beberapa perbankan yang memiliki tingkat kinerja keuangan yang baik, yang di kategorikan memiliki asset dengan jumlah yang relative besar dan juga kinerja keuangan yang baik, sehingga dengan asset yang relative besar mampu menarik investor untuk berinvestasi. Selain itu, perusahaan juga harus mampu meningkatkan nilai perusahaan agar calon investor tertarik untuk menginvestasikan dananya di pasar modal. Jika diasumsikan investor adalah seorang yang rasional, maka investor tersebut pasti akan sangat memperhatikan aspek fundamental untuk menilai ekspektasi imbal hasil yang akan diperolehnya. Bagi perusahaan perbankan yang go publik diharuskan menyertakan rasio keuangan yang relevan sesuai dengan Keputusan Ketua Bapepam Nomor KEP-51/PM/1996 pada tanggal 17 Januari 1996 (BEI).

Harga saham suatu perusahaan mencerminkan nilai perusahaan di mata masyarakat, apabila harga saham suatu perusahaan tinggi, maka nilai perusahaan di mata masyarakat juga baik dan begitu juga sebaliknya. Oleh karena itu harga saham merupakan hal yang sangat penting bagi perusahaan (Nirawati, 2003). Bagi perusahaan yang go public, elemen penting dari nilai perusahaan adalah harga saham, sehingga dalam literature keuangan dikenal nama nilai pasar saham. (Harjito dan Martono, 2005) Nilai perusahaan dapat memberikan kemakmuran pemegang saham secara maksimum apabila harga saham meningkat. Semakin tinggi harga saham sebuah perusahaan maka makin tinggi kemakmuran pemegang saham. Rata - rata nilai CAR perbankan pada tahun 2014 dan 2015 sebesar $15.53 \%$ dan 18.04\%, CAR yang diperoleh perbankan pada tahun tersebut diatas ketentuan Bank Indonesia, yang menetapkan rasio CAR (KPMM) minimal sebesar 8\% . sementara NPL yang diperoleh pada tahun tersebut dibawah ketentuan perbankan, hal ini mengindikasikan bahwa kinerja perbankan jika dilihat dari CAR dan NPL sudah cukup baik. Terlihat juga ROE menunjukkan hasil bahwa keuntungan yang dicapai untuk tahun tahun tersebut diatas $15 \%$. LDR merupakan perbandingan antara kredit yang disalurkan dengan Dana Pihak Ketiga yang dihimpun oleh bank (Giro, Tabungan, dan Deposito). LDR yang baik berada pada kisaran 80 - 110\% (Kasmir, 2014). Semakin tinggi ROE menunjukkan kemampuan bank untuk menghasilkan laba semakin baik yang berarti kinerja bank semakin membaik sehingga dapat mempengaruhi harga saham bank. Hasil penelitian Desi Irayanti (2014) menyatakan kinerja keuangan secara simultan berpengaruh signifikan terhadap nilai perusahaan, namun secara parsial DER berpengaruh signifikan tehadap Nilai Perusahaan Industri Makanan dan Minuman. Hasil penelitian Indra Satria (2015) menyatakan secara parsial LDR dan CAR berpengaruh signifikan terhadap nilai perusahaan. Sementara penelitian Robinhot Gultom (2013) menyatakan secara parsial profitabilitas berpengaruh terhadap Nilai Perusahaan Farmasi. Hasil penelusuran memberikan informasi bahwa CAR, LDR, NPL, DER, dan ROE, mengalami fluktuasi selama 2 Tahun terakhir yang mengindikasikan bahwa kinerja keuangan masingmasing bank cenderung berfluktuas.

\section{Tujuan Penelitian}

Penelitian ini bertujuan untuk mengetahui dan menguji pengaruh Capital Adequacy Ratio (CAR), Loan to Deposit Ratio (LDR), Non Performing Loan (NPL), Debt to Equity Ratio (DER), dan Return on Equity Ratio (ROE) terhadap Nilai Perusahaan secara simultan dan parsial pada sektor perbankan di Bursa Efek Indonsia. 


\section{TINJAUAN PUSTAKA}

\section{Nilai Perusahaan}

Perusahaan didefinisikan sebagai a commercial company (suatu perusahaan komersial) dan ukuran (size) didefinisikan sebagai magnitude (besaran). Sedangkan value didefinisikan sebagai the monetary worth of something : market price (kekayaan moneter dari suatu : harga pasar). Abdurachman mendifinisikan Value atau nilai : (1) dalam istilah ilmu ekonomi pada umumnya adalah kekuatan atau daya sesuatu benda, barang atau jasa untuk menguasai barang-barang atau jasa-jasa lainnya dalam pertukaran (2) dalam keuangan ialah nilai sesuatu, seperti yang ditentukan sesuai dengan salah satu peraturan atau konsepsi. Istilah value pada umumnya berarti harga sesuatu yang akan dapat diperoleh di pasar terbuka atau market valuenya.

Dalam teori keuangan dan ekonomi, harga yang wajar dan adil adalah harga pasar, yaitu harga yang terjadi karena adanya permintaan dan penawaran dari sejumlah besar pembeli atau penjual. Namun metode lainnya juga melihat harga dari sisi apa yang tertulis atau yang tercatat dalam laporan keuangan, ini disebut nilai buku. Menurut Sutrisno (2009) Harga pasar saham mencerminkan nilai riil perusahaan, harga pasar saham dipengaruhi oleh beberapa faktor yakni laba perlembar saham, tingkat bunga bebas risiko dan tingkat ketidakpastian operasi perusahaan. Longbrake (1972), mendefinisikan nilai perusahaan (value of a firm) sebagai investor expectation about the effect of the firm's investment and financial policy. (nilai perusahaan adalah harapan investor atas dampak kebijakan investasi keuangan perusahaan). Teori ini menjelaskan bahwa nilai perusahaan adalah fungsi dari dividend dan tingkat return dari suatu ekuitas. Pada dasarnya, teori ini menyatakan bahwa nilai perusahaan merupakan hasil penilaian dan harapan investor atas saham perusahaan di pasar modal.

\section{Konsep Yang Diteliti}

\section{Capital Adequacy Ratio (CAR)}

Capital Adequacy Ratio (CAR) juga biasa disebut dengan rasio kecukupan modal, yang berarti jumlah modal sendiri yang diperlukan untuk menutup risiko kerugian yang timbul dari penanaman aktiva-aktiva yang mengandung risiko serta membiayai seluruh harta tetap dan investaris bank. CAR atau sering disebut Kebutuhan Penyediaan Modal Minimum (KPMM) sesuai dengan ketentuan Bank Indonesia dikatakan sehat apabila bank memiliki ratio CAR (KPMM) minimal 8\%. Semakin besar Capital Adequacy Ratio (CAR) maka keuntungan bank juga semakin besar. Dengan kata lain, semakin kecil risiko suatu bank maka semakin besar keuntungan yang diperoleh bank (Kuncoro dan Suhardjono, 2002). Rasio yang memperlihatkan seberapa besar jumlah seluruh aktiva bank yang mengandung unsur risiko (kredit, penyertaan, surat berharga, tagihan pada bank lain) yang ikut dibiayai dari modal sendiri bank, disamping memperoleh dana-dana dari sumber-sumber diluar bank (Dendawijaya, 2009).

\section{Hubungan CAR dengan Nilai Perusahaan}

Dendawijaya (2005: 121) berpendapat bahwa CAR adalah rasio yang memperlihatkan seberapa jauh seluruh aktiva bank yang mengandung risiko (kredit, penyertaan, surat berharga, tagihan pada bank lain) ikut dibiayai dari dana modal sendiri bank, seperti dana masyarakat, pinjaman (utang), dan lain-lain. CAR menunjukkan kemampuan manajemen dalam menjamin kecukupan modalnya dengan cara mengidentifikasi, mengawsi dan mengontrol risiko-risiko yang timbul dan dapat berpengaruh terhadap besarnya modal. Dengan kata lain, capital adequacy ratio adalah rasio kinerja bank untuk mengukur kecukupan modal yang dimiliki bank untuk menunjang aktiva yang mengandung atau menghasilkan risiko, misalnya kredit yang diberikan. Dengan CAR yang tinggi, berarti bank mempunyai kemampuan untuk mengatasi kemungkinan kerugian akibat perkreditan dan perdagangan surat-surat berharga. Selain itu, jika CAR tinggi maka masyarakat dan investor akan percaya terhadap kemampuan permodalan bank, dan dana yang diserap dari masyarakat meningkat yang akhirnya akan meningkatkan nilai perusahaan. Besarnya minimal CAR yang diteapkan oleh Banking for International Settlement (BIS) sebesar 8\%, artinya jika CAR berada diangka kurang dari $8 \%$ maka dapat dikatakan bahwa struktur permodalan bank tersebut tidak sehat. Firdaus (2008) menyatakan jika modal bank digunakan untuk menjaga kepercayaan masyarakat, dengan adanya kecukupan modal yang layak, maka investor akan merasa a an untuk menginvestasikan dananya pada perusahaan. Dari paparan teori ini, maka hipotesis pertama yang dapat dibentuk sebagai berikut

H1 : CAR berpengaruh Terhadap Nilai Perusahaa 


\section{Loan to Deposit Ratio (LDR)}

Menurut Surat Edaran Bank Indonesia No 6/23/DPNP tanggal 31 Mei 2004 LDR merupakan rasio kredit yang diberikan terhadap dana pihak ketiga (Giro, Tabungan, Sertifikat Deposito, dan Deposito). Menurut Selamet Riyadi (2006:195) LDR adalah perbandingan antara total kredit yang diberikan dengan total Dana Pihak Ketiga (DPK) yang dapat dihimpun oleh bank. Menurut Kasmir (2014), LDR merupakan rasio untuk mengukur komposisi jumlah kredit yang diberikan dibandingkan dengan jumlah dana masyarakat dan modal sendiri yang digunakan. Standar yang digunakan Bank Indonesia untuk rasio Loan to Deposit Ratio (LDR) adalah 80\% hingga 110\%. Jika angka rasio Loan to Deposit Ratio (LDR) suatu bank berada pada angka di bawah $80 \%$ (misalkan $70 \%$ ), maka dapat disimpulkan bahwa bank tersebut hanya dapat menyalurkan sebesar $70 \%$ dari seluruh dana yang berhasil dihimpun. Jika rasio Loan to Deposit Ratio (LDR) bank mencapai lebih dari $110 \%$, berarti total kredit yang diberikan bank tersebut melebihi dana yang dihimpun. Semakin tinggi Loan to Deposit Ratio (LDR) menunjukkan semakin riskan kondisi likuiditas bank.

\section{Hubungan LDR dengan Nilai Perusahaan}

Dendawijaya (2005: 116) mengatakan bahwa Loan to Deposit Ratio menggambarkan kemampuan bank membayar kembali penarikan yang dilakukan nasabah deposan dengan mengandalkan kredit yang diberikan sebagai sumber likuiditasnya. Semakin tinggi rasio ini memberikan indikasi semakin rendahnya kemampuan likuiditas bank yang bersangkutan. Hal ini disebabkan karena jumlah dana yang diperlukan untuk membiayai kredit menjadi semakin besar. Jadi banyaknya kredit yang diberikan oleh bank kepada masyarakat harus diimbangi dengan kemampuan bank tersebut untuk mengembalikan dana itu. Dengan keseimbangan kemampuan ini maka rasio LDR akan teatp terjaga, serta masyarakat dan dan investor pun akan semakin percaya bahwa bank tersebut dalam kondisi sehat sehingga pada akhirnya nilai perusahaan juga akan meningkat. Dari paparan diatas, dapat dibentuk hipotesis sebagai berikut :

\section{H2 : LDR berpengaruh terhadap Nilai Perusahaan}

\section{Non Performing Loan (NPL)}

Non Performing Loan (NPL) merefleksikan besarnya risiko kredit yang dihadapi bank, semakin kecil Non Performing Loan (NPL), maka semakin kecil pula resiko kredit yang ditanggung pihak bank. Bank dalam memberikan kredit harus melakukan analisis terhadap kemampuan debitur untuk membayar kembali kewajibannya. Setelah kredit diberikan, bank wajib melakukan pemantauan terhadap penggunaan kredit serta kemampuan dan kepatuhan debitur dalam memenuhi kewajiban. Bank melakukan peninjauan, penilaian, dan pengikatan terhadap agunan untuk memperkecil resiko kredit (Ali, 2004) Risiko kredit (default risk) juga dapat terjadi akibat kegagalan atau ketidakmampuan nasabah dalam mengembalikan jumlah pinjaman yang diterima dari bank beserta bunganya sesuai dengan jangka waktu yang telah ditentukan atau dijadwalkan (Idroes, 2008). Menurut Mahmoeddin (2010), NPL adalah kredit yang tidak menetapi jadwal angsuran sehingga terjadi tunggakan. NPL dapat diartikan sebagai pinjaman yang mengalami kesulitan pelunasan akibat adanya factor kesengajaan dan atau karena factor eksternal di luar kemampuan kendali debitur.

\section{Hubungan NPL dengan Nilai Perusahaan}

Non-performing loan (NPL) merupakan rasio yang mempresentasikan risiko yang dimiliki oleh bnk. Rasio non-performing loan menunjukan bahwa kemampuan manajemen bank dalam mengelola kredit bermasalah yang diberikan oleh bank. Sehingga semakin tinggi rasio ini maka akan semakin semakin buruk kualitas kredit bank yang menyebabkan jumlah kredit bermasalah semakin besar maka kemungkinan suatu bank dalam kondisi bermasalah semakin besar dan memungkinkan pencapaian laba semakin rendah (Nasser, 2003). Kredit dalam hal ini adalah kredit yang diberikan kepada pihak ketiga tidak termasuk kredit kepada bank lain. Sebuah bank yang memiliki kinerja yang baik yang tercermin dari rendahnya NPL, diasumsikan ingin menunjukkan baiknya kinerja yang dimilikinya untuk mendapatkan perhatian dari para stakeholder. Dari paparan diatas, dapat dibentuk hipotesis sebagai berikut : 
H3 : NPL berpengaruh negatif terhadap Nilai Perusahaan

\section{Debt to Equity Ratio (DER)}

Rasio ini digunakan untuk membandingkan total utang dengan modal pemilik (ekuitas). Rasio ini juga digunakan untuk mengetahui seberapa bagian dari setiap rupiah dari modal pemilik yang digunakan untuk menjamin utang. Rasio ini mengukur seberapa banyak aset yang dibiayai oleh hutang. Debt to Equity Ratio (DER) merupakan rasio yang digunakan untuk mengukur besarnya proporsi utang terhadap modal. Rasio ini dihitung sebagai hasil bagi antara total utang dengan modal (Hery 2015: 198). Kasmir (2009:157) mendefinisikan Debt to Equity Ratio adalah rasio yang digunakan untuk menilai utang dengan ekuitas. Rasio ini dicari dengan membandingkan antara seluruh utang, termasuk utang lancar dengan seluruh ekuitas. Rasio ini berguna untuk mengetahui jumlah dana yang disediakan peminjam (kreditor) dengan pemilik perusahaan. Dengan kata lain, rasio ini berfungsi untuk mengetahui setiap rupiah modal sendiri yang dijadikan untuk jaminan utang.

Hubungan DER dengan Nilai Perusahaan

Debt to Equity Ratio merupakan rasio yang digunakan untuk menilai utang dengan ekuitas. Rasio ini dicari dengan cara membandingkan antara seluruh utang, termasuk utang lancar dengan seluruh ekuitas. Rasio ini berguna untuk mengetahui jumlah dana yang disediakan peminjam (kreditor) dengan pemilik perusahaan. Dengan kata lain rasio ini berfungsi untuk mengetahui setiap rupiah modal sendiri yang dijadikan jaminan utang. (Kasmir,2008). Biaya utang lebih kecil daripada dana ekuitas dengan menambahkan utang ke dalam neracanya, perusahaan secara umum dapat meningkatkan profitabilitas yang kemudian menaikkan nilai perusahaan, sehingga meningkatkan kesejahteraan para pemegang saham dan membangun potensi pertumbuhan yang lebih besar. Dari paparan tersebut dapat dibentuk hipotesis sebagai berikut :

H4 : DER berpengaruh negative terhadap Nilai Perusahaan

\section{Return On Equity (ROE)}

Return On Equity (ROE) adalah rasio yang menunjukkan kemampuan perusahaan dalam menghasilkan laba bersih dengan menggunakan modal sendiri dan menghasilkan laba bersih yang tersedia bagi pemilik atau investor. ROE membandingkan laba bersih setelah pajak dengan ekuitas yang telah diinvestasikan pemegang saham perusahaan (Van Horne dan Wachowicz, 2005:225). Menurut Tandelilin (2002:269), ROE mereflesikan seberapa besar perusahaan telah memperoleh hasil atas dana yang telah diinvestasikan oleh pemegang saham (baik secara langsung atau dengan laba yang telah ditahan). ROE sangat menarik bagi pemegang saham maupun calon pemegang saham, dan juga bagi manajemen, karena rasio tersebut merupakan ukuran atau indikator penting dari shareholders value cration, artinya semakin tinggi rasio ROE, semakin tinggi pula nilai perusahaan, hal ini tentunya merupakan daya tarik bagi investor untuk menanamkan modalnya diperusahaan tersebut. Menurut Gibson ( 2001:294), Return On Equity measures the return to the common stockholders the residual owner. Pengembalian laba atas ekuitas yang terdiri dari saham biasa merupakan alat ukur terhadap pengembalian laba kepada pemegang saham biasa. Rasio ini menggambarkan berapa persen diperoleh laba bersih bila diukur dari modal sendiri. Semakin tinggi rasio ini semakin baik karena berarti posisi pemilik perusahaan semakin kuat, demikian juga sebaliknya. Return On Equity atau bisa disebut dengan pengembalian ekuitas biasa adalah rasio yang digunakan untuk mengukur seberapa besar pengembalian atas ekuitas biasa. (Brigham dan Houston, 2013).

\section{Hubungan ROE dengan Nilai Perusahaan}

Rasio return on equity digunakan untuk mengukur kinerja manajemen bank dalam mengelola modal yang tersedia untuk menghasilkan laba setelah pajak. Semakin besar ROE suatu bank, semakin besar pula tingkat keuntungan yang dicapai bank tersebut sehingga kemungkinan suatu bank dalam kondisi bermasalah semakin kecil. Laba setelah pajak adalah laba bersih dari kegiatan operasional setelah dikurangi pajak sedangkan rata-rata total ekuitas adalah rata-rata modal inti yang dimiliki bank, perhitungan modal inti dilakukan berdasarkan ketentuan kewajiban modal minimum yang berlaku. Rasio return on equity (ROE) sering digunakan untuk melihat tingkat pengembalian dari dana yang diinvestasikannya. Oleh karena itu, peningkatan dan penurunan return on equity (ROE) mempengaruhi minat dari para investor yang akan berakhir pada putusan investasi yang diambil. Hal ini akan mampu mempengaruhi nilai perusahaan. Suryono dan Prastiwi mengungkapkan bahwa rasio profitabilitas 
merupakan faktor yang mempengaruhi perusahaan untuk melakukan pengungkapan sustainabilitynya. Suryono dan Prastiwi yang didukung oleh Jati menyatakan bahwa pertumbuhan tingkat profitabilitas yang semakin tinggi dan berkesinambungan akan mendorong perusahaan untuk melakukan pengungkapan yang lebih fleksibel dan bebas, namun tidak disepakati oleh Sembiring yang menyatakan tidk adanya pengaruh. Dari pemaparan tersebut dapat dibentuk hipotesis sebagai berikut

H5 : ROE berpengaruh terhadap Nilai Perusahaan

\section{Data dan Sumber Data}

\section{METODE PENELITIAN}

Data yang digunakan dalam penelitian ini adalah data sekunder yang bersumber dari Indonesian Capital Market Directory (ICMD) serta annualreport dari Indonesia Stock Exchange berupa laporan keuangan (beserta ikhtisar-ikhtisarnya) periode tahun 2011 - 2015 dari perusahaan perbankan yang ada di bursa efek Indonesia (BEI) yang bersumber di website www.idx.co.id.

\section{Populasi dan Teknik Pengambilan Sampel}

Populasi dalam penelitian ini adalah sector perbankan yang terdaftar di Bursa Efek Indonesi. Teknik pengambilan sampel yang digunakan dalam penelitian ini adalah dengan metode Judgment Sampling yang merupakan bagian dari purposive sampling (Kuncoro, 2003:119).Adapun tujuan dari metode ini untuk mendapatkan sampel yang sesuai dengan kriteria yang telah ditentukan. Prosedur pemilihan sampel penelitian sebagai berikut: pertama identifikasi jumlah perbankan yang mempublikasikan diri di BEI secara konsisten 5 tahun terakhir kemudian memiliki laba dan ekuitas positif. Adapun sampel penelitian diambil setelah memenuhi beberapa kriteria yang berlaku bagi penerapan definisi operasional variabel. Teknik pengambilan sampel diambil dengan teknik purposive sampling yaitu pemilihan anggota sampel dengan berdasarkan pada kriteria kriteria tertentu.

1. Industri Perbankan yang terdaftar di Bursa Efek Indonesia ( BEI ) sejak tahun 2006 sampai dengan tahun 2015.

2. Industri Perbankan yang membagikan deviden pada periode pengamatan yaitu periode $2006-2015$.

3. Mengambil bank yang memiliki laba dan ekuitas positif.

Jumlah sampel yang memenuhi kriteria dalam penelitian ini adalah sejumlah 7 bank, perbankan yang menjadi sampel dalam penelitian ini adalah sebagai berikut:

1. Bank Central Asia Tbk.

2. Bank Negara Indonesia Tbk.

3. Bank Rakyat Indonesia Tbk.

4. Bank Mandiri Tbk.

5. Bank Danamon Tbk.

6. Bank Tabungan Negara Tbk.

7. Bank Pan Indonesia Tbk.

Sumber: ICMD dan IDX 2016

\section{Metode Analisis dan Teknik Analisa Data}

Teknik analisis yang digunakan dalam penelitian ini adalah teknik analisis kuantitatif, yang merupakan suatu teknik analisa data yang menggunakan angka-angka agar pemecahan masalah dapat dihitung secara pasti dengan perhitungan matematik. Alat analisis yang digunakan adalah uji asumsi klasik dan dilanjutkan dengan analisis regresi linier berganda.

\section{Metode Analisis Regresi Linier Berganda}

Penelitian ini menggunakan analisis regresi berganda dalam melakukan pengujian hipotesis.

Berdasarkan mekanisme hubungan antar variabel maka formulasi matematis dalam penelitian ini adalah sebagai berikut:

Nilai Perusahaan $=\quad a+b 1(\mathrm{CAR})+b 2(\mathrm{LDR})+b 3(\mathrm{NPL})+b 4(\mathrm{DER})+b 5(\mathrm{ROE})+\mathrm{e}$

Dimana :

$\alpha \quad=$ konstanta 


$\begin{array}{ll}b 1, b 2, b 3, b 4, b 5 & =\text { koefisien regresi dari setiap variabel independen } \\ \mathrm{e} & =\text { faktor galat }\end{array}$

\section{Hasil Penelitian}

\section{HASIL PENELITIAN DAN PEMBAHASAN}

\section{Analisis Regresi Berganda}

Analisis regresi berganda merupakan suatu alat analisis yang digunakan untuk mengetahui ada tidaknya pengaruh signifikan antara variable variable bebas (variable independen) terhadap variable terikat (variable dependen).

Adapun hasil pengujian dari pengolahan data model regresi, hipotesis pada table 1 berikut ini:

Tabel 1.Hasil uji Hipotesis

\begin{tabular}{llll}
\hline Variabel & Coefisient & t-test & Sig \\
\hline Constanta & -54953.867 & -3.016 & .007 \\
X_1CAR & & 2.993 & .007 \\
X_2LDR & 1.424 & .171 \\
X_3NPL & 3.274 & .004 \\
X_4DER & -5.597 & .000 \\
X_5ROE & -.418 & .681 \\
R Square & .903 & \\
Adjusted R Square & .877 & \\
F-Statistic & 35.176 & \\
Prob (F-Staistic) & & $.000^{\mathrm{b}}$ \\
\hline
\end{tabular}

Sumber : data sekunder yang diolah

Hasil pengujian persamaan regresi tersebut dapat dijelaskan sebagai berikut:

$Y=(54953.867)+2686.523 X_{1}+436.384 X_{2}+662.351 X_{3}+(2429.992) X_{4}+$

(34.234) $X_{5}$

\section{Pembahasan}

Pengaruh Capital Adequacy Ratio (CAR), Loan To Deposit Ratio (LDR), Non Performing Loan (NPL), Debt to Equity (DER), Return On Equity (ROE)Terhadap Nilai Perusahaan

a. Koefisien regresi untuk variabel CAR adalah sebesar 2686.523 dan bertanda positif, hal ini menjelaskan bahwa setiap perubahan sebesar satu persen pada CAR sementara LDR, Non Performing Loan (NPL), DER dan Return On Equity (ROE) diasumsikan tetap, maka besarnya Harga saham akan mengalami perubahan yakni 
kenaikan sebesar 2686.523. Untuk variabel CAR diperoleh angka $t_{\text {Hitung }}$ sebesar 2.993> $t_{\text {Tabel }}$ pada $\alpha=0.05$ sebesar 1.72913 dan taraf signifikansi lebih kecil dari $\alpha=0.05$ yaitu sebesar 0.007 , dengan demikian maka H1 diterima, artinya ada pengaruh yang positif dan signifikan dari variabel CAR terhadap Nilai Perusahaan. (CAR) berpengaruh positif terhadap Nilai Perusahaan. Ini berarti bahwa peningkatan CAR akan diikuti dengan kenaikan nilai perusahaan, sebaliknya penurunan CAR akan diikuti dengan penurunan nilai perusahaan. Hasil pengujian menunjukkan CAR terbukti berpengaruh positif terhadap nilai perusahaan. Hasil penelitian ini sesuai dengan perkiraan sebelumnya serta sesuai dengan teori investasi. Hasil penelitian ini memberikan pemahaman empiric bagi manajemen bahwa jika CAR naik, maka nilai perusahaan juga naik, kondisi ini menggambarkan bahwa perolehan CAR meningkat berdampak pada kenaikan nilai perusahaan. Semakin besar Capital Adequacy Ratio (CAR) suatu perusahaan akan berpengaruh atau memberikan daya tarik kepada investor untuk percaya dan mau menanamkan dananya, yang pada akhirnya hal ini menyebabkan harga saham naik. Hasil penelitian ini didukung oleh penelitian yang telah dilakukan oleh Ni Putu Lili Indiani (2016) alasannya terjadi karena pembentuk modal bank juga berasal dari modal pelengkap (PMK No 140 / PMK.010 / 2009). Hasil ini didukung oleh penelitian yang dilakukan Mawardi (2005), Puspitasari (2009), Restiyana (2011), Hardiyanti (2012), dan Fahmy (2013) yang menyatakan bahwa CAR berpengaruh positif terhadap ROA. Namun hasil ini berbeda dengan hasil penelitian Suhardi (2013), Fenandi Billian (2015) yang menyatakan bahwa CAR tidak berpengaruh terhadap ROA. Bila dilihat tidak berpengaruhnya CAR terhadap ROA kemungkinan karena bankbank yang beroperasi pada tahun tersebut sangat menjaga besarnya modal yang ada atau dimiliki. Hal ini karena adanya peraturan Bank Indonesia yang mensyaratkan CAR minimal sebesar 8\% mengakibatkan bank-bank selalu berusaha menjaga agar CAR yang dimiliki sesuai dengan ketentuan. Nilai CAR ini diperoleh dari modal bank dibanding dengan ATMR. Seperti yang dikatakan oleh Dendawijaya (2005) bahwa contoh ATMR adalah kredit yang diberikan kepada masyarakat oleh pihak bank. Jadi semakin besar ATMR maka akan menurun nilai dari CAR dan sebaliknya semakin kecil ATMR maka akan meningkat nilai CAR. Dilain pihak, kredit yang diberikan kepada masyarakat dapat membuka kesempatan bank untuk memperoleh pendapatan dari bunga pinjaman yang diberikan. Dengan demikian kemungkinan lainnya CAR tidak berpengaruh terhadap ROA adalah bank belum dapat melempar kredit sesuai dengan yang diharapkan atau belum optimal.

b. Koefisien regresi untuk variabel LDR adalah sebesar 436.384 dan bertanda positif, hal ini menjelaskan bahwa setiap perubahan sebesar satu persen pada LDR sementara CAR, Non Performing Loan (NPL), DER dan Return On Equity (ROE) diasumsikan tetap, maka besarnya Harga saham akan mengalami perubahan yakni kenaikan sebesar 436.384. Untuk variabel LDR diperoleh angka $t_{\text {Hitung }}$ sebesar $1.424<t_{\text {Tabel }}$ pada $\alpha=0.05$ sebesar1.72913 dan taraf signifikansi lebih besar dari $\alpha=0.05$ yaitu sebesar 0.171 , dengan demikian maka $\mathrm{H} 2$ ditolak, artinya tidak ada pengaruh yang positif dan tidak signifikan dari variabel LDR terhadap Nilai Perusahaan. Variabel LDR berpengaruh terhadap nilai perusahaan. Ini berarti bahwa peningkatan LDR akan diikuti dengan nilai perusahaan, sebaliknya penurunan LDR akan diikuti dengan penurunan nilai perusahaan. Hasil pengujian menunjukkan LDR berpengaruh positif terhadap nilai perusahaan. Standar yang digunakan Bank Indonesia untuk rasio Loan to Deposit Ratio (LDR) adalah $80 \%$ hingga $110 \%$. Jika angka rasio Loan to Deposit Ratio (LDR) suatu bank berada pada angka di bawah 80\% (misalkan 70\%), maka dapat disimpulkan bahwa bank tersebut hanya dapat menyalurkan sebesar $70 \%$ dari seluruh dana yang berhasil dihimpun. Jika rasio Loan to Deposit Ratio (LDR) bank mencapai lebih dari $110 \%$, berarti total kredit yang diberikan bank tersebut melebihi dana yang dihimpun. Semakin tinggi Loan to Deposit Ratio (LDR) menunjukkan semakin riskan kondisi likuiditas bank, sebaliknya semakin rendah Loan to Deposit Ratio (LDR) menunjukkan kurangnya efektifitas bank dalam menyalurkan kredit sehingga hilangnya kesempatan bank untuk memperoleh laba. Semakin tinggi Loan to Deposit Ratio (LDR) maka laba bank semakin meningkat (dengan asumsi bank tersebut mampu menyalurkan kreditnya dengan efektif), dengan meningkatnya laba bank, maka kinerja bank juga meningkat. Dengan demikian besar-kecilnya rasio Loan to Deposit Ratio (LDR) suatu bank akan mempengaruhi kinerja bank tersebut. Hasil penelitian menyatakan LDR berpengaruh signifikan terhadap nilai perusahaan. Berpengaruhnya LDR ini kemungkinan karena besarnya kepemilikan aset dari perbankan di Indonesia. Dan kemungkinan yang kedua adalah pendapatan Bank Persero tidak hanya dari pendapatan bunga dari pinjaman yang diberikan kepada masyarakat tetapi juga dihasilkan dari pendapatan berbasis komisi. Hasil penelitian ini juga didukung oleh penelitian Rutanti Indah Mentari (2013), Fenandi Billian (2015), Budi Ponco 
(2015). Namun hasil ini tidak sesuai dengan penelitian Puspitasari (2009), Restiyana (2011), dan Hardiyanti (2012) yang menyatakan bahwa LDR berpengaruh positif dan signifikan terhadap ROA.

c. Koefisien regresi untuk variabel NPL adalah sebesar 662.351 dan bertanda positif, hal ini menjelaskan bahwa setiap perubahan sebesar satu persen pada NPL sementara CAR LDR, DER, dan Return On Equity (ROE) diasumsikan tetap, maka besarnya harga saham akan mengalami perubahan yakni kenaikan sebesar 662.351. Untuk variabel NPL diperoleh angka $\mathrm{t}_{\text {Hitung }}$ sebesar 3.274> $\mathrm{t}_{\text {Tabel }}$ pada $\alpha=0.05$ sebesar 1.72913 dan taraf signifikansi lebih kecil dari $\alpha=0.05$ yaitu sebesar 0.004 , dengan demikian maka H3 diterima, artinya ada pengaruh yang positif dan signifikan dari variabel NPL terhadap Nilai Perusahaan. Variabel NPL berpengaruh positif terhadap Nilai Perusahaan. Ini berarti bahwa peningkatan NPL akan diikuti dengan kenaikan nilai perusahaan, sebaliknya penurunan NPL akan diikuti dengan penurunan nilai perusahaan. Hasil pengujian menunjukkan NPL berpengaruh positif terhadap nilai perusahaan. Hasil penelitian ini tidak sesuai dengan perkiraan sebelumnya serta tidak sesuai dengan teori investasi. Hasil penelitian ini memberikan pemahaman empirik bagi manajemen bahwa jika NPL naik, maka nilai perusahaan akan turun, kondisi ini menggambarkan bahwa perolehan NPL meningkat berdampak pada penurunan nilai perusahaan. Dari hasil deskripsi variabel menunjukkan bahwa pada saat ini tingkat Non Performing Loan (NPL) perusahaan perbankan masih tergolong rendah, yaitu dibawah 5\%. Perusahaan perbankan selalu menjaga agar besarnya Non Performing Loan (NPL) berada dibawah 5\%, hal ini juga yang menjadi penyebab mengapa pada penelitian ini Non Performing Loan (NPL) berpengaruh signifikan terhadap Nilai perusahaan. Kualitas kredit yang buruk akan meningkatkan risiko, terutama bila pemberian kredit dilakukan dengan tidak menggunakan prinsip kehati-hatian dan ekspansi dalam pemberian kredit yang kurang terkendali sehingga bank akan menanggung risiko yang lebih besar pula. Risiko tersebut berupa kesulitan pengembalian kredit oleh debitur yang apabila jumlahnya cukup besar dapat mempengaruhi kinerja perbankan. Hasil penelitian ini didukung oleh Nyimas Villa Dewi, Namun berbeda dengan Saptorini Dyah Lestari (2015) Alasannya investor tidak terlalu memperhatikan tingkat Non Performing Loan (NPL) atau kredit macet yang dihadapi oleh suatu bank jika tingkat NPL yang dihadapi oleh suatu bank masih dibawah batas yang telah ditetapkan oleh Bank Indonesia.

d. Koefisien regresi untuk variabel DER adalah sebesar -2429.992 dan bertanda negatif, hal ini menjelaskan bahwa setiap perubahan sebesar satu persen pada DER sementara Ukuran Perusahaan, Struktur Modal, Non Performing Loan (NPL), dan Return On Equity (ROE) diasumsikan tetap, maka besarnya Harga saham akan mengalami perubahan yakni penurunan sebesar 2429.992. Untuk variabel DER diperoleh angka $t_{\text {Hitung }}$ sebesar (5.597) $>\mathrm{t}_{\text {Tabel }}$ pada $\alpha=0.05$ sebesar 1.72913 dan taraf signifikansi lebih kecil dari $\alpha=0.05$ yaitu sebesar 0.000 , dengan demikian maka $\mathrm{H} 4$ diterima, artinya ada pengaruh yang negative dan signifikan dari variabel DER terhadap Nilai Perusahaan. Variabel DER berpengaruh negatif terhadap Nilai Perusahaan. Ini berarti bahwa penurunan DER akan diikuti dengan kenaikan nilai perusahaan, sebaliknya kenaikan DER akan diikuti dengan penurunan nilai perusahaan. Hasil pengujian menunjukkan DER terbukti berpengaruh negatif terhadap nilai perusahaan. Hasil penelitian ini sesuai dengan perkiraan sebelumnya serta sesuai dengan teori investasi. Hasil penelitian ini memberikan pemahaman empirik bagi manajemen bahwa jika DER naik, maka nilai perusahaan akan turun, kondisi ini menggambarkan bahwa perolehan DER meningkat berdampak pada penurunan nilai perusahaan. Keputusan struktur modal berkaitan dengan pemilihan sumber dana baik yang berasal dari dalam maupun dari luar sangat mempengaruhi nilai perusahaan. Pembiayaan dengan hutang memberikan tiga implikasi penting ; yaitu 1)memperoleh dana melalui hutang membuat pemegang saham dapat mempetahankan pengendalian atas perusahaan dengan investasi yang terbatas; 2) kreditur melihat ekuitas untuk memberikan margin pengaman sehingga jika pemegang saham hanya memberikan sebagian kecil dari total pembiayaan, maka risiko perusahaan sebagian besar ada pada kreditur. 3) jika perusahaan memperoleh pengembalian yang lebih besar atas investasi yang dibiayai dengan dana pinjaman pembayaran bunga, maka pengembalian atas modal pemilik akan menjadi lebih besar dan sebaliknya. Hasil penelitian ini juga didukung oleh Ramadhani Srifitra Fitriani (2016), Mei Yuniati (2016) alasannya Tingkat Struktur Modal yang tinggi akan menimbulkan usaha pengawasan yang lebih besar oleh pihak investor perusahaan sehingga dapat mengurangi perilaku oportunistik manajer dalam Struktur Modal. Hal tersebut dapat berdampak terhadap kenaikkan harga saham karena investor cenderung akan menginvestasikan modal yang dimilikinya. Namun berbeda dengan hasil penelitian Bulan Oktrima (2017), Indah Prisilia (2015), Arie Afzal (2012). 
e. Koefisien regresi untuk variabel ROE adalah sebesar -436.384 dan bertanda negatif, hal ini menjelaskan bahwa setiap perubahan sebesar satu persen pada ROE sementara sementara CAR, LDR, Non Performing Loan (NPL), dan DER diasumsikan tetap, maka besarnya Harga saham akan mengalami perubahan yakni penurunan sebesar 436.384. Untuk variabel ROE diperoleh angka $\mathrm{t}_{\text {Hitung }}$ sebesar $(0.418)<\mathrm{t}_{\text {Tabel }}$ pada $\alpha=0.05$ sebesar 1.72913 dan taraf signifikansi lebih besar dari $\alpha=0.05$ yaitu sebesar 0.681 , dengan demikian maka H5 ditolak, artinya tidak ada pengaruh yang negative dan tidak signifikan dari variabel ROE terhadap Nilai Perusahaan. Variabel ROE berpengaruh positif terhadap Nilai Perusahaan. Ini berarti bahwa kenaikan ROE akan diikuti dengan kenaikan nilai perusahaan, sebaliknya penurunan ROA akan diikuti dengan penurunan nilai perusahaan. Hasil pengujian menunjukkan ROE tidak berpengaruh dan signifikan terhadap nilai perusahaan. Hasil penelitian ini tidak sesuai dengan perkiraan sebelumnya serta tidak sesuai dengan teori investasi. Hasil penelitian ini memberikan pemahaman empirik bagi manajemen bahwa jika ROE naik, maka nilai perusahaan akan turun, kondisi ini menggambarkan bahwa perolehan ROE meningkat berdampak pada penurunan nilai perusahaan. Hasil ini mengindikasikan, semakin besar Return On Equity (ROE) suatu perusahaan tidak berpengaruh /dan tidak memberikan daya tarik kepada investor untuk percaya dan mau menanamkan modalnya dengan membeli saham, hal ini menyebabkan harga saham turun. Hasil penelitian ini didukung oleh Setyorini (2016) alasannya investor tidak terlalu memperhatikan tingkat Return On Equity (ROE) dalam menginvestasikan modalnya akan tetapi lebih melihat trend pasar sehingga Return On Equity (ROE) tidak berpengaruh terhadap Nilai Perusahaan. Namun hasil penelitian ini tidak sejalan dengan hasil penelitian Mei Yuniaty (2016), Indah Prisilia (2015)

Koefisien korelasi linier (R) adalah 0.950. Dari angka ini dapat ditunjukan bahwa hubungan antara variabel bebas $(\mathrm{X})$ dengan variabel terikat $(\mathrm{Y})$ sangat kuat karena hasil koefisien korelasi linier $(\mathrm{R})$ mendekati angka 1, yaitu 0,950 dan angka korelasi yang dihasilkan menunjukan angka positif (+) yang berarti bahwa perubahan salah satu Nilai Variabel, $C A), L D R, N P L, D E R$ dan $R O E$ diikuti perubahan Nilai Variabel yang lainnya secara teratur dengan arah yang sama, diketahui nilai $\mathrm{R}^{2}$ yang dihasilkan sebesar 0.903 atau $90.3 \%$. Angka ini menjelaskan bahwa NilaiPerusahaan sektor Perbankan yang terdaftar di Bursa Efek Indonesia dipengaruhi oleh faktor CAR, LDR, NPL, DER dan ROE sebanyak 90.3\%, sedangkan sisanya sebesar 9.7\% dipengaruhi oleh faktor-faktor atau variable lainnya. Semua variabel independen yakni CAR, LDR, NPL,DER dan ROA secara simultan memiliki pengaruh yang signifikan (bersama-sama) terhadap Nilai Perusahaan. Hal ini diketahui dari hasil uji $\mathrm{F}$, nilai $\mathrm{F}$ yang diperoleh dari perhitungan yang telah dilakukan adalah 35.176 dan nilai ini lebih besar dari nilai F-tabel yang sebesar 2,49 dan nilai signifikan yang berada lebih kecil dari 0,05 yakni 0,000. Hasil ini memenuhi hipotesis bahwa CAR, LDR, NPL, DER dan ROE berpengaruh yang signifikan terhadap Nilai Perusahaan yang dilihat dari nilai Harga saham. Hasil ini juga didukung dengan penelitian Ayuningrum (2011)

Kesimpulan

\section{PENUTUP}

Capital Adequacy Ratio (CAR) berpengaruh positif dan signifikan terhadap nilai perusahaan, Loan to Deposit Ratio (LDR) berpengaruh tidak signifikan terhadap nilai perusahaan,. Non Performing Loan (NPL) berpengaruh dan signifikan terhadap Nilai peusahaan, Debt to Equity Ratio (DER) berpengaruh negative dan signifikan terhadap nilai perusahaan, Return On Equity $(R O E)$ tidak berpengaruh terhadap Nilai Perusahaan, Capital Adequacy Ratio (CAR), Loan to Deposit Ratio (LDR), Non Performing Loan (NPL), Debt to Equity Ratio (DER), Return On Equity (ROE) secara simultan berpengaruh signifikan terhadap Nilai Perusahaan.

\section{Implikasi Teoritis dan Empiris Hasil Penelitian}

Berdasarkan hasil analisis dan pembahasan penelitian ini yang diharapkan dapat memberikan kontribusi pada perkembangan teoritis investasi adalah sebagai berikut :

1. Implikasi teori yang dapat dikemukakan dalam penelitian ini bahwa untuk meningkatkan nilai perusahaan di Pasar Modal dapat menggunakan model faktor internal terhadap Nilai perusahaan.

2. Hasil penelitian ini menemukan bahwa peningkatan nilai perusahaan sebagai akibat menurunkan NPL, serta DER perusahaan perbankan. 


\section{Keterbatasan Penelitian}

Keterbatasan dalam penelitian ini, model yang diajukan adalah model faktor internal terhadap nilai perusahaan dimana model dalam penelitian ini lebih menekankan pada pentingnya menilai faktor internal dalam menentukan nilai perusahaan. Masih banyak variabel yang belum diakomodir pada model ini, perlu menambahkan variabel-variabel lain yang mempengaruhi Nilai Perusahaan, misalnya good corporate governance, perilaku perusahaan, Giro Wajib Minimum (GWM), aktiva produktif bermasalah atau PPAP terhadap aktiva Produktif, menambahkan tentang waktu yang lebih panjang sehingga nantinya diharapkan hasil yang diperoleh akan lebih dapat digeneralisasikan dan lainnya sedangkan untuk faktor eksternal antara lain kebijakan moneter, pertumbuhan ekonomi, persaingan antar perbankan dan perkembangan teknologi sehingga bagi peneliti yang tertarik meneliti tentang nilai perusahaan dapat menambahkan variabel ini. Selain itu keterbatasan yang lain terletak pada objek peneltian, sebaiknya tidak hanya pada industri perbankan saja, tapi lainnya.

\section{DAFTAR PUSTAKA}

Astrid Amanda, dkk. Pengaruh DER, ROE, EPS dan PER terhadap Harga Saham. Jurnal

Bhekti, Fitri Prasetiorini. 2013. Pengaruh Ukuran Perusahaan, Leverage, PER dan Profitabilitas terhadap Nilai Perusahaan, Jurnal Ilmu Manajemen Vol.1 No.1 januari 2013.

Bringham, E.F dan Huston, 2006. Dasar-dasar Manajemen Keuangan, Edisi 10, Alih Bahasa Ali Akbar Yulianto, Penerbit Salemba Empat. Jakarta.

Desi Irayanti. 2014. Analisis Kinerja Keuangan Pengaruhnya Terhadap Nilai Perusahaan Pada Industri Makanan Dan Minuman Di BEI. Jurnal EMBA 1473 Vol.2 No.3 September 2014

Etna Nur Afri yuyetta, 2009, Pengaruh Leverage Terhadap Nilai Perusahaan Pada Masa Krisis: Pengujian Empiris Di Indonesia, Jurnal Akuntanssi \& Auditing Vol.5/No.2/ Mei 2009

Hermuningsih, Sri. 2012, Pengaruh Profitabilitas, Size Terhadap Nilai Perusahaan Dengan Stuktur Modal Sebagai Variable Intervening, Jurnal Siasat Bisnis Vol. 16 No. 2 Juli 2012

Indra Satria Dan Iha Haryani Hatta, 2015, Pengaruh Kinerja Keuangan Terhadap Harga Saham 10 Bank Terkemuka Di Indonesia, Jurnal Akuntansi Vol. XIX No. 02 Mei 2015

Kasmir, 2014. Analisis Laporan Keuangan, PT. Raja Grafindo Persada, Jakarta.

Mahendra, Alfredo. 2012. Pengaruh Kinerja Keuangan Terhadap Nilai Perusahaan Pada Perusahaan Manufaktur Di Bursa Efek Indonesia. Jurnal Manajemen, Strategi Bisnis, dan Kewirausahaan Vol. 6, No. 2 Agustus 2012

Martono dan Harjito, Agus. 2007. Manajemen Keuangan. Ekonosia. Yogyakarta.

Mawar Sharon R. Pantow, 2015. Analisa Pertumbuhan Penjualan Ukuran Perusahaan, ROA, dan Struktur Modal terhadap Nilai Perusahaan yang tercatat di Indeks LQ45. Jurnal Emba, vol.3 No.1 maret 2015.

Morenly Welley, 2015, Faktor-Faktor Yang Mempengaruhi Nilai Perusahaan Di Sektor Pertanian Pada Bursa Efek Indonesia Tahun 2010 - 2013, Jurnal Emba, Vol. 3 No. 1 Maret 2015

Robinhot Gultom, 2013, Analisis Factor-Faktor Yang Mempengruhi Nilai Perusahaan Pada Perusahaan Farmasi Di Bursa Efek Indonesia, Jurnal Wira Ekonomi Mikroskil, Vol 3, Nomor 01 April 2013

Sartono, A. 2008, Manajemen Keuangan Teori dan Aplikasi, Edisi 4 Penerbit BPFE, Yogyakarta. 
Pertiwi, Tri Kartika. Pengaruh Kinerja Keuangan, GCG terhadap Nilai Perusahaan Food And Beverages. Jurnal

Tulung, Joy Elly, and Dendi Ramdani. 2018. Independence, Size and Performance of the Board: An Emerging Market Research. Corporate Ownership \& Control, Volume 15, Issue 2, Winter 2018.

Wangari, Andreas R., dkk. 2015. Pengaruh Tingkat ROI, NPM, DER terhadap Harga Saham Perbankan di Bursa Efek Indonesia, Jurnal Emba Vol. 3 No. 4 desember 2015.

Wijaya, Anthony. 2015. Pengaruh Kinerja Keuangan terhadap Nilai Perusahaan. Jurnal FINESTA Vol. 3, No. 1,

www.idx.co.id 